\title{
Hungarian Accounting Standardization Effects
}

\author{
Professor Dr. Gyorgy Csebfalvi \\ Dept. of Business Information Systems, Pecs University \\ PO Box 80, Street of Rakoczi, City of Pecs, Hungary, Europe
}

Tel: 36-72-501-599

Received: January 29, 2012 Accepted: March 02, 2012 DOI: 10.5296/ijafr.v2i1.1457

\begin{abstract}
Nowadays, especially during the current global financial crisis, companies in Hungary are striving desperately to remain competitive and achieve sustainable levels of economic development. The highly competitive environment requires companies to create a clear business strategy, and accounting has to be part of this strategy since it helps individual enterprises to achieve their strategic objectives. International accounting standards are new global methods for business information systems and they are able to harmonize financial regimes both in Hungary and world-wide. The increased globalization of markets, the complexity of commercial trading and the concentration of business in global competition have led to a still greater need for international accounting harmonization. It is expected that a unified, standardized accounting information system will lead to new types of analysis and data with the possible integration of new indicators used in the business practice of certain countries as an additional benefit.

The purpose of this study was to measure the differences between national (Hungarian)l rules and the international standards, evaluating and analyzing their effects on the business environment. The financial data are taken from accounts published on the Budapest Stock Exchange and in the Hungarian Business Information database. The results show that those businesses which have adopted international standards achieved higher and statistically significant positive coefficients than those following local accounting rules. We found that larger firms (those with more leverage, higher market capitalization and substantial foreign sales) were more likely to have adopted international accounting standards.
\end{abstract}

Keywords: Accounting standards, Standardization, Harmonization, Globalization, Balance sheet and P\&L effects, Value relevance, Hungary. 


\section{Introduction}

Nowadays, especially during the current global financial crisis, companies in Hungary are striving desperately to remain competitive and achieve sustainable levels of economic development. The highly competitive environment requires companies to create a clear business strategy, and accounting has to be part of this strategy since it helps individual enterprises to achieve their strategic objectives. International accounting standards are new global methods for business information systems and they are able to harmonize financial regimes both world-wide and in Hungary also. The increased globalization of markets, the complexity of commercial trading and the concentration of business in global competition have led to a still greater need for international harmonization.

Attempts to understand the crisis and to reflect on its implications also illustrate the dangers of the drift away from the world of accounting practice - a characteristic of so much accounting research over the last few decades. It is extremely important to understand how accounting has become implicated with the creation of new financial practices, with objectifying and simplifying the increasingly complex financial transactions which have emerged from ever-expanding investment in financial engineering. Equally significant is the need for a more informed understanding of the changes which have occurred in the influence structures in the world of accounting politics (both national and international) and of the changing role which accounting plays in the informational environment of organizations.

The International Accounting Standards Board (IASB) has planned to develop a uniform and understandable global accounting convergence (Easton, 2006), and the IASB's plan has resulted in more than 100 countries world-wide now requiring, permitting or adopting International Financial Reporting Standards (IFRS) (Epstein, 2009). This growing acceptance of IFRS has also influenced emerging economies (Ball, Robin and Wu, 2003). Beke (2010a:49) asserted that "the purpose of the use of international accounting information systems is that similar transactions are treated the same by companies around the world, resulting in globally comparable financial statements". These findings have led many authors to conclude that global comparability will be driven by factors other than the accounting standards. In particular, most authors point to either regulatory oversight or capital market pressures (Burgstahler, Hail and Leuz, 2006).

Researchers have suggested that the best approach to assessing the applicability of IFRS is to evaluate the convergence process in emerging markets (Lere, 2009; Cordazzo, 2008; Jones and Higgins, 2006). However, the process of adoption has been the subject of limited research, since researchers themselves have suggested that it would be better to use national case studies to analyze the adoption of IFRS in individual nations. Examples of this are Callao-Jarne-Lainez (2007) in Spain, Cormier-Demaria-Lapointe-Teller (2009) in France, Lantto and Sahlström (2009) in Finland, Iatridis and Rouvolis (2010) in Greece, Peng and Smith (2010) in China and Beke (2010b) in Hungary also.

The research undertaken in the form of national case studies will develop guide-lines on best 
practice in the implementation of IFRS in order to assist developing countries and countries with economies in transition to succeed in their efforts to harmonize their national accounting rules and practice with international requirements

Earlier literature shows that the level of the capital market orientation of the financial environment also follows the differences in accounting systems internationally. Examples of this are found when the Common Law accounting systems of the USA and the UK are compared with Code Law-based systems of many Continental European countries (see, for example, La Porta, 1998).

Earlier studies show that, in Code Law countries (e.g., in Europe) the capital provided by banks tends to be more important than in Common Law countries e.g., the USA and Canada) where firms are mainly financed by a large number of private investors (Barth et al., 2004). Therefore, information asymmetry between capital providers and the company is likely to be resolved in Code Law countries by providing accounting information to the capital providers by means of high-quality, public financial reporting (e.g. Beke, 2010c).

Previous studies also show that the adoption of IFRS improves the accounting quality of publicly traded companies in Europe (Daske and Gebhardt, 2006; Zeff, 2007). Overall, the adoption of IFRS seems to benefit investors, especially in countries which resemble Code Law clusters and where the information needs of investors were not the primary interest of standards setters (Nobes, 2007).

Additionally, many papers examine the properties of accounting information across different accounting regimes. Overall, these studies indicate that similar accounting methods are applied very differently around the world. However, Beke (2011a) remarked that "the unified accounting information system will probably lead to new types of analysis and data - with the possible additional integration of new indicators from the practice of certain countries".

International Financial Reporting Standards are accounting principles or methods (i.e. 'standards') issued by the IASB, an independent organisation based in London. They were intended to be a set of standards which, ideally, would apply equally to financial reporting by public companies worldwide. Between 1973 and 2000, international standards were issued by IASB's predecessor organisation, the International Accounting Committee (IASC), a body established in 1973 by the professional accountancy bodies in Australia, Canada, France, Germany, Japan, Mexico, Netherlands, the UK and Ireland, and by the United States. During that period the IASC's principles were described as 'International Accounting Standards' (IAS). In April 2001 the rule-making function was assumed by a newly reconstituted IASB, at which point the IASB re-labelled its rules as 'IFRS'. Nonetheless, it continues to recognise the previous rules (IAS) issued by the old standard-setter (IASC). The IASB is better funded, better staffed and more independent than its predecessor, the IASC, but there has, in fact, been a considerable degree of continuity over the years in terms of the professional perspective and in actual accounting standards. 
Standardization is the term used to describe the reconciliation of different points of view - a more practical concept than uniformity, which suggests imposing one country's accounting rules on all others. Organizations, private or public, need information to coordinate their various investments in different sectors of the economy. With the growth of international business transactions by private and public entities, the need to coordinate different investment decisions has increased. A suitable accounting information system can help multinational enterprises accomplish their managerial functions on a global basis. Further, standardization of the manner in which reports are prepared can greatly enhance the value of accounting systems to their users and increase transparency to investors and regulators.

Historically, the standardisation of international accounting methods has tended to follow the integration of the markets served by the accounts. For example, the move to unified national accounting in the US in the early $20^{\text {th }}$ century followed the integration of the national economy. Similarly, the present move towards global accounting standards follows the accelerating integration of the world economy.

Without common accounting standards, cross-border portfolio and direct investment may be distorted, cross-border monitoring of management by shareholders obstructed and cross-border contracting inhibited, costs being needlessly inflated by complex translation

The purpose of the use of international accounting methods is that a single set of standards ensures similar transactions are treated the same by companies around the world, resulting in globally comparable financial statements. However, looking at accounting standards as consistently by firms, we see that they are changeable since they depend on the varying economic, political, and cultural conditions in one state. Accounting standard-setters and regulators around the globe are planning to harmonize accounting standards with the goal of creating one set of high-quality rules to be applied world-wide (Whittington, 2008).

\section{Hungarian accounting standardization practice}

Hungary has had more than 100 years of experience in national accounting. A first attempt to define and compile the value of national income and national wealth in Hungary was made in 1855 , and the next important step in the development of national accounting was the compilation of national accounts for the period 1920-30. A new period, of course, started in 1950, in accordance with a general reorganisation of the state apparatus and the introduction of soviet-type central planning The theoretical basis of the new, official national accounts was the Marxian concept of "productive work' accounting, in which only the production of material goods creates original income, a theory pre-dating Marx to Adam Smith and Ricardo.

In Hungary, current legal accounting requirements have been in force since 1991, with the Ministry of Finance being responsible for accounting and auditing regulation. For the operation of a market economy, it is, of course, essential that objective information based on past data be 
available on the financial and earnings position of companies, non-profit organisations and other types of economic organisation, as well as on their development, in order for market players to be able to make sound decisions based on available information

The Act contains accounting rules which are in harmony with the relevant directives of the European Communities and with international accounting principles. It basically demands reliable information, providing an accurate and true overall picture of the income-producing capability, the use of assets, the financial situation and the future plans of the enterprise (Beke, 2011b).

The Act authorizes the Government to decree:

a) reporting and bookkeeping obligations of budgetary organizations, the special turnoverrelated definitions used for annual accounts and bookkeeping in line with the provisions laid down in the Act concerning the State Budget;

b) special regulations concerning the annual accounts and bookkeeping obligations of the National Bank of Hungary, of credit institutions, financial firms, insurance companies, the stock exchange, clearing houses and other similar bodies providing clearing or settlement services, investment funds and other funds, following consultation with the national Bank of Hungary- (These regulations concerning the activities and the requirements of the body designated to maintain the register of providers of accounting services, the procedure for the admission into and removal from the register, the detailed regulations for keeping the register, compulsory professional training, and the legal remedies available).

The Accounting Act incorporates very detailed accounting requirements based on the Fourth and Seventh EU Company Law Directives and IFRS. From 2005 these Standards will apply only to the legal entity financial statements of companies and to the consolidated financial statements of non-listed companies which do not opt to present financial statements prepared in accordance with IFRS.

The Hungarian Accounting Standards Board was recently established to take over the responsibility for setting Hungarian Accounting Standards (HAS) from the Ministry of Finance. The Board was established by Decree 2002 of 2003 under the authority of the Accounting Act. Its establishment reflects the desire of the Ministry of Finance for accounting standards to be developed by the accounting and auditing professions rather than by government.

HAS, according to a 2004 World Bank assessment of accounting and auditing practices in Hungary, differ from International Financial Reporting Standards, despite significant efforts at harmonization. Being a European Union member, Hungary complies with the European Commission (EC) Regulation No. 1606/2002, which requires the application of IFRS in the preparation of consolidated financial statements of listed companies. The $2008 \mathrm{EC}$ report on the implementation of Regulation No. 1606/2002 points out that Hungary permits the 
application of IFRS in consolidated accounts of all entities within the scope of the Act on Accounting, but not in annual accounts. The use of IFRS in the annual accounts is allowed for informal purposes only. In this respect, the 2004 World Bank assessment recommended the adoption of IFRS for all public interest entities in the country.

In June 2009, the World Bank conducted a review of accounting and auditing practices in Hungary in order to evaluate the weaknesses and strengths of the accounting and auditing requirements and to compare the reporting requirements with actual practice. International Financial Reporting Standards (IFRS), formerly International Accounting Standards (IAS), and International Standards on Auditing (ISA) were used as the benchmarks for assessing national standards. The Report on the Observance of Standards and Codes (ROSC) was published in the same year, summarizing the results of the assessment and suggesting a reform agenda. The report noted that the Hungarian accounting framework is governed by the Act on Accounting, which is based on the EU's 4th and 7th Directives on the harmonization of accounting standards. The Act on Accounting lays down Hungarian Accounting Standards and is supplemented by government decrees based on special requirements for banks, insurance companies, stockbrokers, investment funds, pension funds, and various non-profit institutions. As detailed in the ROSC, in addition to the Accounting Act, the financial statements of banks must comply with Government Decree No. 250/2000 on Special Provisions Regarding the Annual Reporting and Bookkeeping Obligations of Credit Institutions and Financial Enterprises. For insurance companies, the Accounting Act is supplemented by Decree No. 192/2000 on Reporting and Bookkeeping Requirements of Insurers. According to the description of the regulatory framework provided in the 2005 Chamber of Hungarian Auditors (MKVK) self-assessment, the securities market, banks, and insurance companies are regulated by the Hungarian Financial Supervisory Authority (PSZAF). All listed companies, banks, and insurance companies are required to prepare and publish quarterly financial statements, which are reviewed by the PSZAF, whilst sanctions for non-compliance include delisting from the stock exchange. With regard to banks and insurance companies, the PSZAF can also perform and on-site inspections when irregularities are suspected and further action can include a suspension of both auditor and management. In addition to quarterly reporting, banks are also required to submit an overall supervisory report every two years.

The Accountancy Act promulgates the Europe Agreement establishing an association between Hungary and the European Communities and their Member States, signed on 16 December 1991 in Brussels, and this Act contains regulations which should be fully aligned with the following legal regulations of the European Communities:

a) Fourth Council Directive of 28 July 1978 on the Annual Accounts of certain types of company (78/660/EEC),

b) Seventh Council Directive of 13 June 1983 on Consolidated Accounts (83/349/EEC).

c) Directive 2001/65/EC of the European Parliament and of the Council of 27 September 2001 amending Directives 78/660/EEC, 83/349/EEC and 86/635/EEC in respect of Valuation 
rules for the Annual and Consolidated Accounts of certain types of company as well as of banks and other financial institutions,

d) Regulation No. 1606/2002/EC of the European Parliament and of the Council of 19 July 2002 on the application of International Accounting Standards,

e) Eleventh Council Directive 89/666/EEC of 21 December 1989 concerning disclosure requirements in respect of branches opened in a Member State by certain types of company governed by the law of another State.

The detailed regulations, methods and procedures implemented to supplement the legal provisions which are necessary for the principle of true and fair view shall be prescribed in national accounting standards. These national accounting standards shall not contradict the objectives and principles of this Act, nor the process of harmonization of legal systems defined in Act I of 1994 promulgating the Europe Agreement establishing an association between the Republic of Hungary and the European Communities and their Member States, signed in Brussels.

\section{Methodology}

The purpose of this study was to measure the differences between national rules and the international methods, evaluating and analyzing their effects on the economic environment. This survey also includes information on how international accounting standards have been affected by the global economic crisis. To examine decisions made by companies to adopt IFRS, we created a sample comprising Budapest Stock Exchange (BSE) companies who adopted IFRS in Hungary in 2007. For the purpose of research, the pre-adoption period was 2006 and the post-adoption 2008. The final sample consists of 65 companies who adopted IFRSs and 260 Hungarian firms using local accounting rules. The specific samples are of conventional shareholder companies with Hungarian headquarters who employ an average of more than 50 people..

The financial data are taken from accounts published on the Budapest Stock Exchange and in the Hungarian Business Information database. In our sample, the firms are classified as either 'following international standards' or as 'using national accounting rules"

Basically, we used a qualitative comparative approach, but to identify the results of our research, we elaborated three hypotheses:

$\mathbf{H}_{\mathbf{1}}$ : Balance Sheet indices deteriorated - especially in respect of solvency and prosperity after adopting IFRS.

$\mathbf{H}_{2}$ : Heavy losses tend not to be infrequent after IFRS adoption decisions.

$\mathbf{H}_{3}$ : Business management has higher value relevance after the post-adoption period.

\subsection{Accounting methods and balance sheet effects}

This set of analyses measures how Hungarian enterprises have been affected in terms of business performance by IFRS. The logistic regression models employed are (see Barth et al., 2005) $(1,2)$ : 


$$
\begin{aligned}
\text { RR }_{i, t}=a_{0}+a_{1} \text { Size }_{i, t} & +a_{2} \text { Dividend }_{i, t}+a_{3} \text { Frowth }_{i, t}+a_{4} \text { Profitability }_{i, t}+ \\
& +a_{5} \text { Liquidity }_{i, t}+a_{6} \text { Leverage }_{i, t}+\mathrm{e}_{\mathrm{i}, \mathrm{t}} \\
\text { PA }_{i, t}=a_{0}+a_{1} \text { Size }_{i, t} & +a_{2} \text { Dividend }_{i, t}+a_{3} \text { Growth }_{i, t}+a_{4} \text { Profitability }_{i, t}+ \\
& +a_{5} \text { Liquidity }_{i, t}+a_{6} \text { Leverage }_{i, t}+\text { ei }_{, t}
\end{aligned}
$$

Where:

$\mathrm{RR}_{\mathrm{i}, \mathrm{t}}=$ dummy variable, indicating the regulatory system,

- $\mathrm{RR}_{\mathrm{i}, \mathrm{t}}=1$, financial numbers are reported by IFRS,

- $\mathrm{RR}_{\mathrm{i}, \mathrm{t}}=0$, financial numbers are reported by National GAAP,

$\mathrm{PA}_{\mathrm{i}, \mathrm{t}}=$ dummy variable, indicating the post-adoption effects.

- $\mathrm{PA}_{\mathrm{i}, \mathrm{t}}=1$, financial numbers are reported by IFRS in 2007

- $\mathrm{PA}_{\mathrm{i}, \mathrm{t}}=0$, financial numbers are reported by IFRS in 2006 .

Size: Natural logarithm of market capitalization:

- NAVSH: Net asset value per share

- RESSFU: Reserves to shareholders' funds

Dividend: $\quad$ - DIVCOV: Dividend cover

- DIVSH: Dividend per share

- DIVYI: Dividend yield.

Growth: $\quad-\quad$ MVBV: $\quad$ Market value to book value

Profitability: - EPS: $\quad$ Earnings per share

- NPM: Net profit margin

- ROCE: Return on capital employed

Liquidity: $\quad-$ CFM: $\quad$ Cash flow margin

- CUR: Current ratio

- OCF: Operating cash flow scaled by total assets

- QUI: Quick ratio

- WCR: Working capital ratio

Leverage: - DEBTE: Debt to equity

- DSFU: Debt to shareholders' funds

- CGEAR: Capital gearing

$\mathrm{e}_{\mathrm{i}, \mathrm{t}}=$ the error term.

\subsection{Accounting methods and $P \& L$ effects}

This part of our research examined whether firms determine small positive profits rather than large losses. .Our analysis employed the next model (see also Tarca, 2004) (3):

$$
\begin{aligned}
R_{i, t}=a_{0} & +a_{1} \text { Profitability }_{i, t}+a_{2} \text { Dividend }_{i, t}+a_{3} \text { Growth }_{i, t}+ \\
& +a_{4} \text { Size }_{i, t}+a_{5} \text { Liquidity }_{i, t}+a_{6} \text { Leverage }_{i, t}+ \\
& +a_{7} \text { SP }_{i, t}+a_{8} L_{i, t}+e_{i, t}
\end{aligned}
$$

Where:

$\mathrm{SP}_{\mathrm{i}, \mathrm{t}}=$ dummy variable indicating a measure of small positive profits. 
$\mathrm{SP}_{\mathrm{i}, \mathrm{t}}=1$ if net profit scaled by total assets is between 0 and 0.01 ,

$\mathrm{SP}_{\mathrm{i}, \mathrm{t}}=0$ otherwise.

$\mathrm{LL}_{\mathrm{i}}, \quad=$ dummy variable indicating a measure of timely loss recognition.

$\mathrm{LL}_{\mathrm{i}, \mathrm{t}}=1$ if net profit scaled by total assets is less than -0.20 ,

$\mathrm{LL}_{\mathrm{i}, \mathrm{t}}=0$ otherwise.

\subsection{Accounting methods and value relevance}

The first value relevance test is an OLS regression of share price on book value per share and net profit per share (see Hung and Subramanyam, 2007) (4).

$$
P_{i, t}=a_{0}+a_{1} B V P S_{i, t}+a_{2} N P P S_{i, t}+e_{i, t}
$$

Where:

$\mathrm{P}_{\mathrm{i}, \mathrm{t}} \quad=$ Total market value of equity deflated by number of shares outstanding,

BVPS $_{\mathrm{i}, \mathrm{t}}=$ Total book value of equity deflated by number of shares outstanding,

NPPS $_{i, t}=$ Total net profit deflated by number of shares outstanding.

The second value relevance test is an OLS regression of profits on stock returns (5).

$$
N P P_{i, t}=a_{0}+a_{1} A R_{i, t}+e_{i, t}
$$

Where:

$\mathrm{NPP}_{\mathrm{i}, \mathrm{t}}=$ Net profit divided by beginning of year share price,

$\mathrm{AR}_{\mathrm{i}, \mathrm{t}}=$ Annual stock return at year-end.

The third value relevance test measured the association between IFRS-based book value and net profit figures, then stock returns (6).

$$
A R_{i, t}=a_{0}+a_{1} B V P S_{i, t}+a_{2} B V C H A_{i, t}+a_{3} N P P S_{i, t}+a_{4} N P C H A_{i, t}+e_{i, t}
$$

Where::

BVCHA $_{i, t}=$ Variable indicating the change in corporate book value following the transition to IFRS,

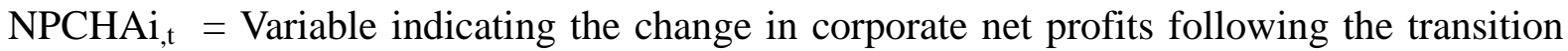
to IFRS. 


\section{Results}

The results of hypotheses $\mathrm{H}_{1}$ are reported in Table 1 .

Table 1. Accounting method effects

\begin{tabular}{|l|r|r|r|r|}
\hline \multirow{2}{*}{ Denomination } & \multicolumn{2}{|c|}{ National GAAP-using firms } & \multicolumn{2}{|c|}{ IFRS adopted firms } \\
\cline { 2 - 5 } & Mean & $\begin{array}{r}\text { Std. } \\
\text { deviation }\end{array}$ & Mean & $\begin{array}{r}\text { Std. } \\
\text { deviation }\end{array}$ \\
\hline & & & & \\
DIVSH & 0,0846 & 0,1986 & 0,1557 & 0,2106 \\
DIVYI & 17,5764 & 19,8721 & 22,8705 & 25,4457 \\
MVBV & 5,8152 & 7,8125 & 2,5478 & 8,1547 \\
NPM & $-0,2945$ & 4,5412 & $-0,1031$ & 7,4581 \\
EPS & 0,1987 & 1,0561 & 0,1897 & 1,5061 \\
ROCE & 0,2008 & 0,3051 & $-0,0081$ & 0,6401 \\
OCF & 3,8812 & 15,4421 & 4,8512 & 16,8041 \\
CUR & 1,9911 & 6,9105 & 2,9814 & 3,1125 \\
CFM & 0,8029 & 2,3126 & $-0,0408$ & 1,5974 \\
DEBTE & 1,9843 & 2,3566 & 2,3099 & 2,1577 \\
CGEAR & 0,3454 & 0,2325 & 0,8714 & 0,3115 \\
DSFU & 0,3258 & 0,1353 & 0,5469 & 0,8540 \\
& & & & \\
\hline
\end{tabular}

(Source: Author's own constructions)

It can be seen in Table 1 that the average index of dividend per share (from earnings after tax) is higher at companies which had already adopted IFRS than in others. However, the relative average value (DIVYI) contains a high deviation (the deviation value is almost 30 in respect of companies using IFRS).

The companies applying the National Accounting Rules earn more than double $(5,8152)$ in terms of growth (measured by market value to historical value of assets) than do other firms. In this sense the IFRS-adopting companies' average index is much lower.

The companies examined had a negative average net profit value (loss) in both groups in the period covered, although the return on equity and the average return on capital employed gave better results for National Accounting Rules users. The latter index showed a declining tendency $(-0,0081)$ at companies which adopted the IFRS.

The National Accounting Rules-using companies' average indices measuring solvency (OCF, CUR, CFM) and leverage were higher than the others. Cash Flow, for instance, decreased $(-0,0408)$ at IFRS-adopting companies, although around the relative average value of Operating Cash Flow on assets the deviation is quite high (between 15 and 17). As the 


\section{Macrothink}

International Journal of Accounting and Financial Reporting

ISSN 2162-3082

2012, Vol. 2, No. 1

indebtedness of companies using National Regulations was lower, the leverage indices (DEBTE, CGEAR, DSFU) were better than in those companies which had adopted IFRS.

To summarize, we can state that Balance Sheet indices deteriorated especially regarding solvency and prosperity after the adoption of IFRS.

The results of model (3) are reported in Table 2.

Table 2. Small Profit or Large Losses

\begin{tabular}{|l|c|r|}
\hline Denomination & IFRS adopted firms & $\begin{array}{r}\text { National GAAP- } \\
\text { using firms }\end{array}$ \\
\hline SP & $-1,194^{* *}$ & 0,451 \\
\hline LL & $2,581^{*}$ & 1,324 \\
\hline
\end{tabular}

(Sourse: Author's own constructions)

$*$ at $10 \%$ level significance,

$* *$ at $5 \%$ level significance..

The data in the Table 2 prove that the companies which had already adopted IFRS were less willing to hide profit in the P\&L. Account when it was low, and by doing so, the probability of reporting a small profit (SP) was significantly negative $(-1,194)$ in their case.

Further, we can state that neither did they did tend to hide a large loss. The latter statement is a consequence of the positive and high value of the coefficient of $\operatorname{LL}(2,581)$. It is specific for National Accounting Rules-using companies to favour reporting smaller profits $(0,451)$ and avoid large losses being reported in $\mathrm{P} \& \mathrm{~L}$ Account - which is possible when using accrual-based accounting. 
The results of value relevance models are summarized in Table 3.

Table 3. Accounting methods and value relevance

\begin{tabular}{|l|l|l|}
\hline \multirow{2}{*}{ Denomination } & \multicolumn{2}{|c|}{ Coefficients } \\
\cline { 2 - 3 } & National GAAP-using firms & IFRS adopted firms \\
\hline NPPS & $2,041^{* *}$ & $3,025 * *$ \\
\hline BVPS & $0,547 * *$ & $1,354 * *$ \\
\hline AR & $2841,145^{* *}$ & $3694,124 *$ \\
\hline BVCHA & $0,1941^{* *}$ & $0,2941 *$ \\
\hline NPCHA & $0,0182 * *$ & 1,3541 \\
\hline R & 0,689 & 0,799 \\
\hline *Statistical significance at $10 \%$ level, & $* *$ Statistical significance at $1 \%$ level. \\
\hline
\end{tabular}

(Source: Author's own construction)

Our $\mathrm{H}_{3}$ assumption, namely that the information system of companies who adapted IFRS shows a higher value relevance than other national accounting rules-user companies, is proved by the data of Table 3 .

The first test of value relevance gave a result for earnings after tax/share (EPS) coefficient $(3,025)$ and for book value of equity/share $(1,354)$ which is significantly (at $1 \%$ ) positive and higher at IFRS-adopting companies than at others. These companies also had more profitable, higher correlation coefficients of financial indices $\left(R^{2}=0,799\right)$.

The second test of value relevance gave similar results since the coefficient of Return on Equity (ROE) is also significantly (at $10 \%$ ) positive and higher $(3694,124)$ at companies which have already adopted IFRS.

The coefficient of Book Value Change $(1,3541)$ produced turned out significantly more positive at IFRS-adopting companies according to the third test of value relevance. These results obviously prove that the companies which adopted IFRS have an orientation towards a reporting policy based on greater reliability and more realistic evaluation. However, the index presenting the change of Net Profit (NPCHA) was also positive (but not significantly) at these companies (1,3541).

\section{Conclusion}




\section{Mll Macrothink}

International Journal of Accounting and Financial Reporting

ISSN 2162-3082

2012, Vol. 2, No. 1

Standardization of accounting systems has tended to follow the integration of the markets employed by the accounts. The present impetus for global accounting standards follows the accelerating integration of the word economy. The global accounting standards would enable the world's stock markets to become more closely integrated. The more closely world's stock markets approach a single market, therefore, the lower should be the transaction costs for investors and the cost of capital for firms in that market. The differences in international reporting practice prior to IFRS constituted a palpable barrier to efficient international investment, monitoring and contracting. And the literature suggest that being confined to small segmented capital markets imposes a substantially larger cost of capital on firms and transaction costs on investors, which would inhibit much worthwhile investment. Although we do not have all elements for the cost-benefit calculation, the evidence points to substantial net gains for smaller economies which have joined to the IFRS regime. There is certainly empirical research evidence to support the notion that uniform financial reporting standards will increase market liquidity, decrease transaction costs for investors, lower cost of capital, and facilitate international capital formation and flow. And there is a sufficient basis to endorse IFRS and begin the challenging task of educating users, auditors, and regulators Educators and practicing accountants alike have significant roles to play in this exciting future.

Reporting according to IFRS provide much better access to world capital markets, which reduces the cost of capital. Investors cannot easily interpret the given countries' national financial reports. They are very reluctant to invest in companies without clear financials. It is high risk to invest in companies without easily accessible, clear financial reports. Investors expect higher returns from these businesses, thus the cost of debt is higher for the businesses not preparing IFRS reports. IFRS would put the financial statements in a simple and understandable form for investors and other businesses interested in the firm. IFRS financial reports could have a positive effect on businesses' credit ratings thus the cost of borrowing may be reduced. Also, IFRS are widely accepted as the financial reporting framework for companies who would like to get admitted to any of the world's stock exchanges. Since worldwide adoption of IFRS would create a common language for accounting, new capital markets would open to companies who have been reporting only in accordance with their national standards. One can easily say that companies have the opportunity to prepare their financials according to IFRS.

We noted that the Balance Sheet indices deteriorated, especially regarding solvency and prosperity after adoption of IFRS. The results show that those businesses which have adopted international standards achieved higher and statistically significant positive coefficients than did those following local accounting rules. We found that larger firms (those with more leverage, higher market capitalization and substantial foreign sales) were more likely to have adopted international accounting standards. Among these firms, lower profits are declared less frequently - possibly indicative of the quality of earnings management. Standards adopted firms displayed small profit less frequently possibly indicating less earnings management and they did recognise large losses when they occurred. Companies which had 


\section{Macrothink}

International Journal of Accounting and Financial Reporting

ISSN 2162-3082 2012, Vol. 2, No. 1

adopted IFRS also provided higher quality and value relevant accounting information systems.

The accounting system differences matter even to financial analysts who specialize in collecting, measuring and disseminating business information about the covered companies suggests that there are potential economic costs, associated with variation in national rules across countries. Besides it is very important task for managers and researchers the valuation and analyzing the effects of international accounting standards on business decisions, especially their contribution to standardization and globalization.

\section{Discussion}

After the measuring some economic effects of accounting standardization on business environment and achieving some results the author decided that we need to continue this analyzing process using interdisciplinary methods also, because it can be reach the whole real picture of globalized unified financial statements. We would like to advise them for accounting researchers and practitioners to employ these methods and measure their effects on business functions.

\section{References}

Ball,R., Robin,A. and Wu,S. (2003). The effect of international institutional factors on properties of accounting earnings.. Journal of Accounting and Economics, Vol. 29. No. 6. pp. 417-434.

Barth,E., Landsman,R. and Lang,H. (2004). International Accounting Standards and Accounting Quality. Research Paper, Stanford University Graduate School of Business.

Beke, J. (2010a). International Accounting Information Systems. Lambert Academic Publishing, Berlin, Germany, p.116.

Beke, J. (2010b). Review of International Accounting Information Systems. Journal of Accounting and Taxation, Vol. 2. No.2., pp. 25-30.

Beke, J. (2010c): International Accounting Harmonization: Evidence from Europe. International Business and Management, Vol. 1. No. 1. pp. 48-61.

Beke, J. (2011a). International Accounting Standards Effects on Business Management. Business Management and Strategy, Vol. 2., No.1: E3, pp.1-12.

Beke, J. (2011b). Comparative Analysis of International Accounting Information Systems. International Journal of Finance and Accounting, Vol. 1. No. 1. pp. 55-83.

Burgstahler,D., Hail,L. and Leuz,C. (2006). The importance of reporting incentives: earnings 


\section{Macrothink}

International Journal of Accounting and Financial Reporting ISSN 2162-3082 2012, Vol. 2, No. 1

management in European private and public firms, International Business Review, 23: 48-69.

Callao, S., Jarne, J. and Lainez, J. (2007): Adoption of IFRS in Spain: Effect on the comparability and relevance of financial reporting. Journal of International Accounting, Auditing and Taxation, Vol. 16. No. 2. pp. 148-178.

Cordazzo, M. (2008): The impact of IAS/IFRS on accounting practices: evidence from Italian listed companies. Working Paper, Free University of Bozen-Bolzano, Italy

Cormier, D., Demaria, S., Lapointe, P, and Teller, R. (2009): First-Time Adoption of IFRS, Managerial Incentives, and Value-Relevance: Some French Evidence. Journal of International Accounting Research, Vol. 8, No. 2. pp. 1-22.

Daske,H. and Gebhardt, G. (2006). International Financial Reporting Standards and Experts. Perceptions of Disclosure Quality.. Abacus, Vol. 42. No.3/4. pp. 59-71.

Easley,D. and Hara,.M.,(2004), Information and the Cost of Capital., The Journal of Finance., Vol..59, No. 9. pp..59-71.

Easton, P. (2006). Use of forecasts of earnings to estimate and compare cot of capital across regimes. Journal of Business Finance \& Accounting Research, Vol.. 23. No. 2. pp. 49-71.

Epstein, B.J. (2009). The Economic effects of IFRS Adoption.. The CPA Journal, Vol.24. No.3: pp. 26-31.

Hung, M. and Subramanyam, R. (2007). Financial statement effects of adopting international accounting standards: The case of Germany. Review of Accounting Studies, Vol.41, No.12. pp. 21-48.

Iatridis,G. and Rouvolis,S. (2010). The post-adoption effects of the implementation of International Financial Reporting Standards in Greece, Journal of International Accounting, Auditing and Taxation, Vol. 19, No. 1. pp.: 55-65.

Jones, S. and Higgins, D. (2006): Australia's switch to international financial reporting standards: a perspective from account preparers, Journal of Accounting and Finance, Vol 46., No. 9. pp. 629-652.

Lantto, M. and Sahlström,P. (2009): Impact of International Financial Reporting Standard adoption on key financial ratios. Journal of Accounting and Finance, Vol. 49. No. 5. pp. 341-361.

La Porta, R. (1998). Law and Finance, The Journal of Political Economy, Vol. 106. No. 9. 


\section{Al Macrothink \\ International Journal of Accounting and Financial Reporting \\ ISSN 2162-3082 2012, Vol. 2, No. 1}

pp. 1113-1155.

Lere,J.C.(2009). Benchmarking Accounting Practices in a Global Economy..The CPA Journal, Vol.10, No.11: pp. 10-12.

Nobes.G. (2007). A Survey of National Accounting Rules Benchmarked Against International Accounting Standards. London . $9^{\text {th }}$ Edition.

Peng, S and Smith, L. (2010) Chinese GAAP and IFRS: An analysis of the convergence process. Journal of International Accounting, Auditing and Taxation, Vol. 19, No. 1. pp. $16-34$.

Tarca, A. (2004). International convergence of accounting practices: Choosing between IAS and U.S. GAAP. Journal of International Financial Management and Accounting, Vol.15. No.6, pp. 60-91.

Whittington,G. (2008). Harmonization or discord? The critical role of IASB conceptual framework review, Journal of Accounting and Public Policy, Vol.27. No. 11. pp. 495-502.

Zeff,R. (2007). The Empirical Economics of Standards. DTI, Economics Paper. Vol.19, No.12. London: Department of Trade and Industry. 